\title{
Degradation of Gesaprim Herbicide by Heterogeneous Photocatalysis Using Fe-Doped $\mathrm{TiO}_{2}$
}

\author{
Noemí Acevedo Quiroz ${ }^{1}$, Dulce Jocelyn Ramos Gutierrez ${ }^{1}$, Susana Silva Martínez ${ }^{2}$, \\ Cristina Lizama Bahena ${ }^{1}$ \\ ${ }^{1}$ Posgrado de la Facultad de Ciencias Químicas e Ingeniería y Centro de Investigación en Ingeniería y Ciencias \\ Aplicadas, Universidad Autónoma del Estado de Morelos, Cuernavaca, Mexico \\ ${ }^{2}$ Centro de Investigación en Ingeniería y Ciencias Aplicadas, Universidad Autónoma del Estado de Morelos, \\ Cuernavaca, Mexico \\ E-mail: ssilva@uaem.mx
}

Received June 21, 2011; revised August 7, 2011; accepted September 26, 2011

\begin{abstract}
Fe-doped $\mathrm{TiO}_{2}$ was prepared by the sol gel method and characterized by X-ray diffraction. All the Fe-doped $\mathrm{TiO}_{2}$ were composed of an anatase crystal form. The activity of the $\mathrm{Fe}$-doped $\mathrm{TiO}_{2}$ for the degradation of the gesaprim commercial herbicide (which contains atrazine as active compound and formulating agents) was studied by varying the iron content during UV $(15 \mathrm{~W})$, visible light and solar irradiations. The visible light came from commercial saving energy lamps $(13,15$ and 20 Watts). The gesaprim degradation rate depended on the iron content in the photo catalyst. The Fe-doped $\mathrm{TiO}_{2}\left(0.5 \%\right.$ by weight of $\left.\mathrm{TiO}_{2}\right)$ showed higher TOC removal under visible light and was more active than the undoped $\mathrm{TiO}_{2}$ photo catalyst under the light irradiation sources tested. Over $90 \%$ of chemical oxygen demand abatement was achieved with both UV and visible light but less time was required to decrease the chemical oxygen demand content by using the catalyst doped with iron at $0.5 \%$ under visible light. It was observed that the degradation of gesaprim increased by increasing the iron content in the catalyst under visible light.
\end{abstract}

Keywords: Atrazine, Iron Doped $\mathrm{TiO}_{2}$, Solar Irradiation, Visible Light Irradiation

\section{Introduction}

Nowadays, the use of herbicides in agriculture activities to control weedy plants and to increase food production has become an important tool to the detriment of the en- vironment. The herbicides and their degradation products (complex metabolites) may alter the natural habitats for different plant and animal species depending on how they are transported in the environment. Chlorinated tri- azines are herbicides widely used for selective weed control, and are amongst the most commonly used herbicides in the world [1]. The main compound of this family is the atrazine (2-chloro-4-ethylamino-6-isopropylamino-s-triazine) and it is found in the environment contaminating soil and water reserves [2]. This herbicide belongs to the persistent organic pollutants because of its low biodegradability and long half-life (60 and 100 days) in water.

Several processes have been developed to remove atrazine from aqueous wastes, such as activated carbon and its combination with ozone $[3,4]$, adsorption onto carbon nanotubes [5], adsorption onto zeolites [6], adsorption on fractionated Al-pillared and Fe-Al-pillared clays [7], photochemical degradation in the presence of hydrogen peroxide and microwave [8], reverse osmosis [9], ozone [10], hydrogen peroxide with ozone [11], electro-Fenton [12], Fenton and photo-Fenton [13], photolysis by $\mathrm{TiO}_{2}$ semiconductor [14-18], atrazine by nanoscale zero valent iron supported on organobentonite [19], and hydrogen peroxide with $\mathrm{TiO}_{2}$, and $\mathrm{Fe}_{2} \mathrm{O}_{3}$ semiconductor suspensions assisted by light [20-22], among others.

Amongst the treatment methods, the semiconductor photocatalytic process for the photocatalytic oxidation mediated by titanium dioxide appears to be an effective strategy for degrading chlorinated triazine herbicides because the semiconductor has shown a great potential as a low-cost, and environmental friendly alternative for wastewater treatment. Besides, this advanced oxidation process has been widely demonstrated to remove persistent organic compounds and microorganisms in water. The photocatalytic oxidation of s-triazine herbicides and 
the pathways of their degradation intermediates have been reported by several studies $[22,23]$. It has been concluded that the oxidation of the lateral chains and subsequent disappearance of the initial compound is very fast, but the formation of the final product (cyanuric acid) may require a long irradiation time [23]. Also, it has been reported that complete mineralization of atrazine could not be attained because of the stability of the striazine ring toward oxidation which only affects the lateral chains with 5 of the 8 carbons removed as $\mathrm{CO}_{2}$. Hustert et al. studied the photocatalytic treatment of atrazine herbicide, and also other s-triazine herbicides (simazine, and cyanzine) [19]. These researchers reported that the degradation of the s-triazines occurred in various steps with cyanuric acid was formed as end product of degradation. Hequet et al. studied the photolytic degradation of atrazine and found that the UV photolysis was efficient [24]. They reported that the main degradation pathway was deshalogenation and hydroxyatrazine was generated as the main intermediate with cyanuric acid as the final end product. These authors also studied the photocatalytic degradation of atrazine, and found that the major intermediates were desalkylated compounds with cyanuric acid as the final degradation product. McMurray and coworkers reported that the primary pathway for atrazine degradation on nanoparticulate $\mathrm{TiO}_{2}$ films involved the oxidation of the lateral side chains of atrazine, producing dealkylated derivatives (2chloro-4-acctamido-6-isopropylamino-1,3,5-triazine, 2chloro-4-ethylamino-6-(2-propanol)amino-1,3,5-triazine, 2-chloro-4-ethylamino-6-(2-propanol)amino-1,3,5-triazin e, desethylatrazine, deisopropylatrazine and desethyldesisopropyl atrazine) [16]. They also reported that the hydrolysis of the chlorine substituent in desethylatrazine, desethyldesisopropyl atrazine and deisopropylatrazine led to the production of 2-hydroxydesethyl atrazine with the further displacement of the amino groups by hydroxyl groups resulting in cyanuric acid. These authors proposed a secondary pathway which follows a hydroxylated pathway with immediate substitution of the chlorine at position two with a hydroxyl group. They neither observed complete mineralization of atrazine nor photolysis of atrazine either with the UVA or UVB source. Peñuela and Barceló studied the photo degradation of atrazine and desethylatrazine in water with $\mathrm{TiO}_{2} /$ $\mathrm{H}_{2} \mathrm{O}_{2}$ and $\mathrm{FeCl}_{3} / \mathrm{H}_{2} \mathrm{O}_{2}$ by using a xenon arc lamp and sunlight irradiation [25]. These authors reported that atrazine degraded faster than desethylatrazine in the presence of $\mathrm{FeCl}_{3}$ using both light sources with half-lives varying from 5 to $11 \mathrm{~min}$ and from 19 to $26 \mathrm{~min}$, respectively. Měšt'ánková et al., reported that the degradation rate of the herbicide monuron was enhanced when $\mathrm{TiO}_{2}$ was in contact with $\mathrm{Fe}$ (III) (from $\mathrm{Fe}\left(\mathrm{ClO}_{4}\right)_{3}$ ) because the
$\mathrm{Fe}(\mathrm{III})$ acted as scavenger of electrons photogenerated in $\mathrm{TiO}_{2}$ particles which let down hole-electron recombination [26].

The doping with small amounts of metal impurities aims at facing one relevant drawback of $\mathrm{TiO}_{2}$, which is its poor absorption of visible light. Enhanced visible light absorption has been reported in the presence of transition metals [27,28], nitrogen and carbon as dopants [29]. It was reported that the UV-Vis absorption studies showed significantly enhanced red-shift in UV-Vis absorption spectra with an increased amount of iron [30,31]. The photocatalytic activity of nano-sized $\mathrm{Fe}$-doped $\mathrm{TiO}_{2}$, examined by the mineralization of oxalic acid under visible light irradiation, showed highest activity with $2 \%$ of Fe-doped $\mathrm{TiO}_{2}$ [31]. However, it was reported that the photocatalytic efficiency of metal doped $\mathrm{TiO}_{2}$ strongly depends on the conditions of preparation, on the morphostructural properties (crystalline structure, specific surface area) and on the type of the organic pollutant to be photooxidized.

The aim of this work was to synthesize $\mathrm{TiO}_{2}$ and irondoped $\mathrm{TiO}_{2}$ with the sol-gel method and to study the efficiency of Fe-doped titania suspensions in the photocatalytic degradation of the gesaprim commercial herbicide under UV light, visible light and solar light. Gesaprim, herbicide used for the control of broadleaf weeds and some grassy weeds, contains atrazine as active compound and formulating agents as additional components.

\section{Material and Methods}

\subsection{Chemicals}

Gesaprim herbicide (90 GDA) was directly purchased from Syngenta Crop Protection Inc. (USA); the gesaprim contained $90 \%$ of atrazine as active ingredient. Titanium tetrabutoxide $\left(\mathrm{Ti}\left(\mathrm{OC}_{4} \mathrm{H}_{9}\right)_{4}\right)$, anhydride ethanol, distilled water, ferric chloride $\left(\mathrm{FeCl}_{3}\right), \mathrm{HNO}_{3}$ and $\mathrm{H}_{2} \mathrm{SO}_{4}$ were analytical grade (Sigma-Aldrich). All chemicals were used as received without further purification.

\subsection{Synthesis of Fe-Modified $\mathrm{TiO}_{2}$ Photo Catalyst}

The Fe-doped $\mathrm{TiO}_{2}$ catalyst was prepared by the sol-gel method as below: A mixture of $\mathrm{H}_{2} \mathrm{O}(1.25 \mathrm{ml}), \mathrm{HCl}(0.5$ $\mathrm{ml}), \mathrm{C}_{2} \mathrm{H}_{6} \mathrm{O}(5 \mathrm{ml})$ and $\mathrm{FeCl}_{3}$ (different iron amounts) was prepared with stirring for $5 \mathrm{~min}$. Separately, $\mathrm{Ti}\left(\mathrm{OC}_{4} \mathrm{H}_{9}\right)_{4}$ solution at a concentration of $44.7 \mathrm{~g} / \mathrm{l} \mathrm{ex}-$ pressed as $\mathrm{TiO}_{2}$ was added drop wise to $22.5 \mathrm{ml} \mathrm{C}_{2} \mathrm{H}_{6} \mathrm{O}$ solution $(99.9 \%)$ with stirring under nitrogen atmosphere, this solution was kept under stirring during $20 \mathrm{~min}$. Then, the iron mixture was added drop by drop to the ethanol- 
titanium tetrabutoxide solution and kept under stirring during $2 \mathrm{~h}$ until a gel was formed. The content of iron was $0.0 \%, 0.1 \%$ and $0.5 \%$ by weight of $\mathrm{TiO}_{2}$. Afterwards, the solvent was eliminated under vacuum. The resulting powder was dried at $100^{\circ} \mathrm{C}$ for $30 \mathrm{~min}$ followed by thermal treatment at $400^{\circ} \mathrm{C}$ with air during $2 \mathrm{~h}$. The crystal structure of the powders was studied by X-ray diffraction on a diffractometer (Rigaku model DMAX 2200) with $\mathrm{Cu} \mathrm{Ka}$ radiation $(\lambda=1.54439 \AA)$ at $2 \theta=0^{\circ}-80^{\circ}$, and the morphology by the scanning microscope electron (LEO $1450 \mathrm{VP})$.

\subsection{Photocatalytic Degradation of Gesaprim Herbicide}

The photocatalytic degradation of gesaprim was carried out employing white fluorescent light (visible light from an energy saving compact lamp), UV and solar irradiation. Gesaprim degradation, using $\mathrm{TiO}_{2}$ and Fe-doped $\mathrm{TiO}_{2}$ suspension of the powders synthesized, was followed by measuring the chemical oxygen demand (COD) and Total organic carbon (TOC). The initial concentration of gesaprim which corresponds to its maxima solubility in water at $\mathrm{pH} 3$ is $40 \mathrm{ppm}$. Such concentration has a COD and TOC content of 38 ppm and 20 ppm, respectively. The photocatalytic activity of the photo catalyst Fe-doped $\mathrm{TiO}_{2}$ was evaluated by measuring the decomposition rate of gesaprim in a circulation type reactor. The reactor was similar to a laboratory glassware condenser (made of glass Duran ${ }^{\mathrm{TM}}, 20 \mathrm{~cm}$ long and $4 \mathrm{~cm}$ inner diameter). The UV or visible lamp was put inside the inner glass tube of the condenser so that the irradiation of the UV/Vis light was $\sim 2 \mathrm{~mm}$ away from the flowing gesaprim solution; while the gesaprim solution was running in a similar way that a coolant does in a laboratory glassware condenser using a centrifugal polypropylene circulating pump (Cole Parmer). Stock solutions of gesaprim $(0.106 \mathrm{~g}$ diluted in $2.5 \mathrm{~L})$ were prepared with distilled water at $\mathrm{pH} 3$ adjusted with $\mathrm{H}_{2} \mathrm{SO}_{4}$ with gentle stirring during $2 \mathrm{~d}$. The $\mathrm{TiO}_{2}$ (iron doped/ undoped) slurry solution, containing $40 \mathrm{ppm}$ of initial concentration of gesaprim at $\mathrm{pH} 3$, in the reactor was irradiated with a UV light (15 W, $352 \mathrm{~nm}$, Cole Parmer) or energy saving white fluorescent light $(13,15$, and 20 W compact lamps, Phillips). The UV illumination intensity at the surface of the sample was $0.068 \mathrm{~W} / \mathrm{cm}^{2}$; whereas it varied inside of $0.059-0.090 \mathrm{~W} / \mathrm{cm}^{2}$ range for the visible light. The gesaprim solution was in contact with the photo catalyst for $20 \mathrm{~min}$ previous to switch the lamp on. The COD of gesaprim in the reactor were measured as a function of the photocatalytic degradation time which started at the moment the lamp was on; whereas TOC was analyzed when the experiment was terminated. COD and TOC were analyzed using standard methods and standard tubes (Hach) inside the concentration range of 0 - 40 ppm. Samples were filtered as collected prior the analysis.

\section{Results and Discussion}

\subsection{Characterization of Undoped $\mathrm{TiO}_{2}$ and Iron Doped $\mathrm{TiO}_{2}$ Powders}

Figure 1 shows the XRD patterns of the $\mathrm{TiO}_{2}$ and $0.5 \%$ Fe doped $\mathrm{TiO}_{2}$ powder annealed at $400^{\circ} \mathrm{C}$. According to the main reflection, the observed peaks can be attributed to the anatase phase. Regarding to the Fe-doped $\mathrm{TiO}_{2}$, the diffraction peaks for iron are completely missing from the XRD pattern for the doped iron $\mathrm{TiO}_{2}$ powder. This may be attributed to the low sensitivity of the XRD method due to the low concentration of added iron [32]. It could also be attributed to the incorporation of iron ions in the crystal structure of $\mathrm{TiO}_{2}$ [33], or by very fine dispersion of iron in the titania resulting in X-ray amorphous behavior [32]. Ambrus and coworkers doped the titania with iron up to $10 \%$ of iron content (Fe(III)) and the diffraction peaks for iron were completely missing from the XRD pattern for the doped iron $\mathrm{TiO}_{2}$ powder [32].

\subsection{Influence of Iron on the Photo Catalyst for the Degradation of Gesaprim under Visible Light}

The photocatalytic activity of the Fe-doped $\mathrm{TiO}_{2}$ was observed for the decomposition of gesaprim which was carried out employing white fluorescent light (visible light) and solar irradiation. The COD decay profile for the decomposition of gesaprim (Figure 2(a)) increased by the presence of iron in the $\mathrm{TiO}_{2}$ photo catalyst (400 $\mathrm{mg} / \mathrm{L}$ ) under visible light irradiation (with $0.090 \mathrm{~W} / \mathrm{cm}^{2}$ using $20 \mathrm{~W}$ lamp). The highest initial degradation rate of

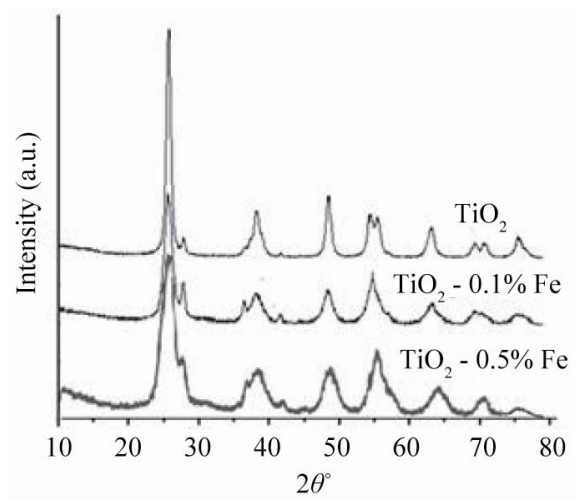

Figure 1. XRD patterns of $\mathrm{TiO}_{2}$ and iron-doped $\mathrm{TiO}_{2}$ powder. 
gesaprim was found to be at $0.5 \%$ of iron content (by weight of $\mathrm{TiO}_{2}$ ) achieving $95 \%$ of COD removal after 60 min of visible light irradiation (with an energy consumption of $288 \mathrm{~kJ} / \mathrm{L}$ ) which corresponds to a TOC removal of $\sim 50 \%$ at the same time. Increasing the degradation time further, it was observed that TOC was decreased $90 \%$ of its original value $(20 \mathrm{ppm})$ at $200 \mathrm{~min}$ of photo reaction.

While the undoped $\mathrm{TiO}_{2}$ photo catalyst showed $\sim 21 \%$ of COD removal at the same time under the same conditions. The degradation of gesaprim under solar irradiation (in a cloudless day from 10:00 to 14:00 h) is shown in Figure 2(b). It can be seen from this figure that the initial COD decay (decomposition rate) of gesaprim is fast in the first 10 minutes and then the decomposition of gesaprim slows down. COD abatements of 13\%, 36\% and $65 \%$ were, respectively, achieved by undoped $\mathrm{TiO}_{2}$, $0.1 \%$ Fe-doped $\mathrm{TiO}_{2}$ and $0.5 \%$ Fe-doped $\mathrm{TiO}_{2}$ after 60 minutes under solar irradiation at $\mathrm{pH} 3$ (with an energy consumption of $267.9 \mathrm{~kJ} / \mathrm{L}$ ). TOC removal of $\sim 23 \%$ was achieved using $0.5 \%$ Fe-doped $\mathrm{TiO}_{2}$ under solar light at $60 \mathrm{~min}$ of reaction. These results show that the increased activity of $\mathrm{TiO}_{2}$ doped with iron is because of the nature of iron which can be an electron or hole scavenger and results in the improvement of the separation of free car-

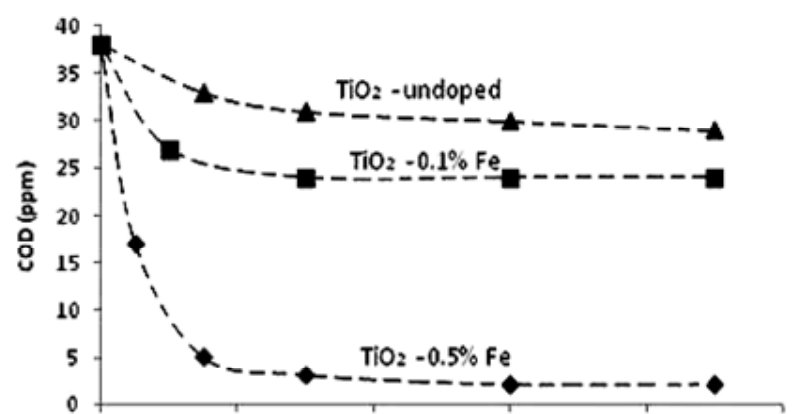

(a)

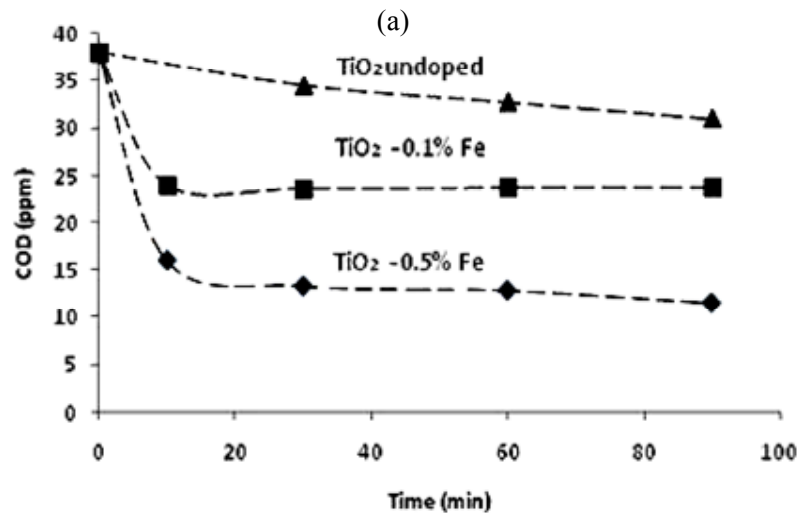

(b)

Figure 2. COD profile for the degradation of gesaprim using $\mathrm{TiO}_{2}$ and iron-doped $\mathrm{TiO}_{2}$ (catalyst load: $400 \mathrm{ppm}$ and $\mathrm{pH}$ ) under (a) visible light (20 W) and (b) solar irradiation. riers. Thus, the recombination rate of the electron-hole pairs is lowered and the photocatalytic activity is enhanced. It has been reported that the photocatalytic activity of iron doped $\mathrm{TiO}_{2}$ strongly depends on the preparation method, iron precursor, and the amount and state of iron (commonly a very low content of doped iron has a positive effect on the enhancement of the photocatalytic activity of Fe-doped $\mathrm{TiO}_{2}$ ).

It has also been reported that higher amount of Fe(III)doped $\mathrm{TiO}_{2}$ than an optimal iron content is detrimental on the photocatalytic activity of the photo catalyst because the $\mathrm{Fe}(\mathrm{III})$ at high concentration in $\mathrm{Fe}$-doped $\mathrm{TiO}_{2}$ can act as a recombination centres [34].

\subsection{Influence of Light Irradiation on the Photo Catalyst for the Degradation of Gesaprim}

In order to study the effect of light source on the degradation of gesaprim by $0.5 \% \mathrm{Fe}$-doped $\mathrm{TiO}_{2}$ catalyst, several experiments were carried out and recorded as a function of the energy consumption to compare the degradation efficiency of gesaprim for each light source. It was used different power lamps (Figure 3) and different source of light irradiation (Figure 4) to record the COD abatement profiles during the degradation of gesaprim.

Figure 3 reports that the initial rate of COD abatement is fast and similar in the first 100 minutes of degradation regardless of the power of the lamp used. Afterwards, the COD was $95 \%$ abated when the lamp of the higher power $(20 \mathrm{~W})$ was used in which it was required $<300$ $\mathrm{kJ} / \mathrm{L}$ of energy consumption (after $60 \mathrm{~min}$ of photo catalysis), attributable mainly to visible-light absorption by the iron compound; whereas, only $85 \%$ of COD was abated with the other two lamps even at higher energy consumption.

The profiles for COD abatement using different sources

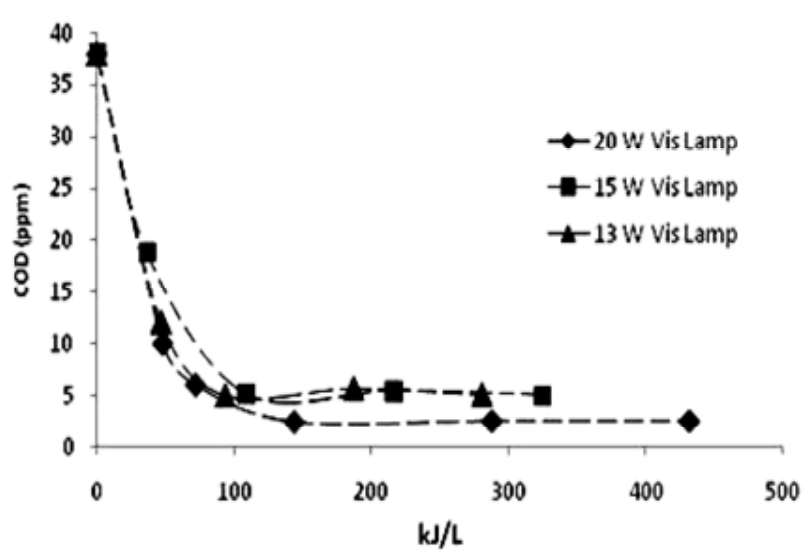

Figure 3. COD removal profile for the degradation of gesaprim using $400 \mathrm{ppm}$ of $0.5 \%$ Fe-doped $\mathrm{TiO}_{2}$ under different powers of the visible light. 

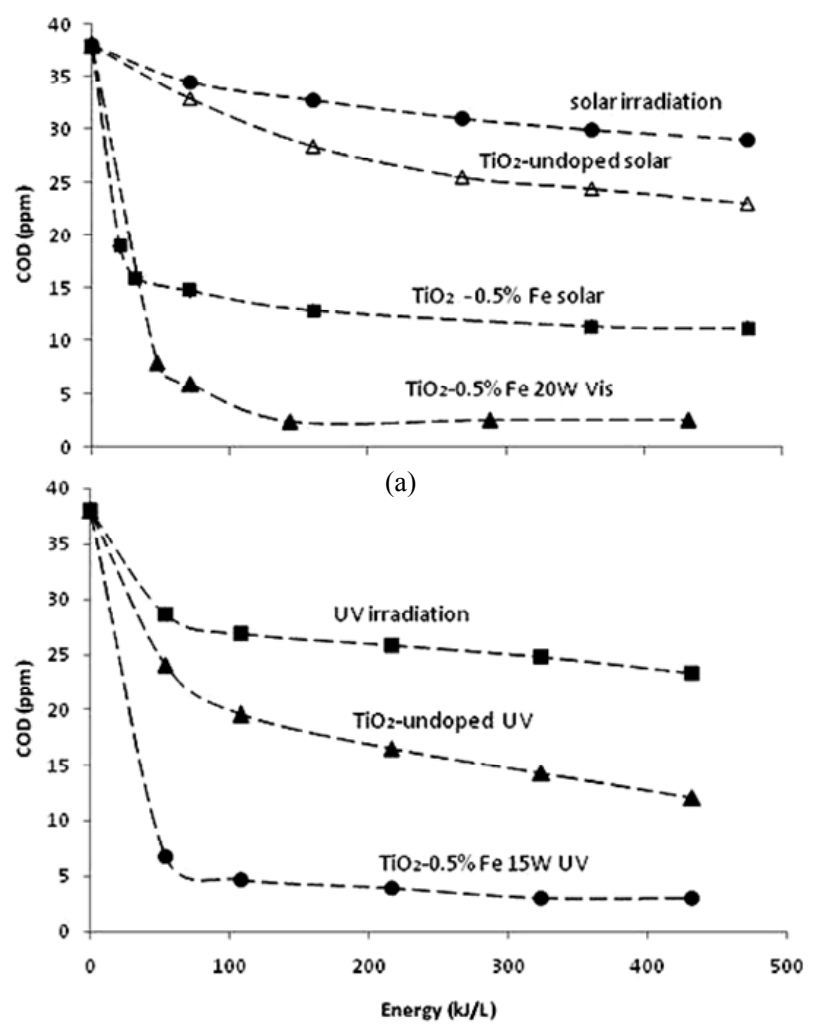

(b)

Figure 4. Photocatalytic degradation of gesaprim using 400 ppm of $0.5 \%$ Fe-doped $\mathrm{TiO}_{2}$ under different sources of light irradiation.

of light irradiation (Figure 4) clearly show an improvment in the degradation of gesaprim by the presence of iron in the catalyst $\left(0.5 \% \mathrm{Fe}\right.$-doped $\left.\mathrm{TiO}_{2}\right)$ under visible light from both the $20 \mathrm{~W}$ Vis-lamp and the solar irradiation (Figure 4(a)).

It is interesting to observe that the iron-doped $\mathrm{TiO}_{2}$ enhanced the initial rate of COD removal under the solar irradiation with respect to that obtained with or without undoped $\mathrm{TiO}_{2}$ under similar energy efficiency. Thus, the iron in the catalyst increased the reactivity of the photo catalyst under the visible-light of the solar irradiation. COD removals of $23 \%, \sim 40 \%$ and $74 \%$ were achieved by the sole effect of solar photolysis, solar photo catalysis and solar Fe-doped photo catalysis, respectively. The activation of the catalyst under solar irradiation is by both visible and UV irradiation (with $\sim 6 \%$ of UV light contribution [35]. This figure also shows that $95 \%$ of COD removal was obtained by the Fe-doped $\mathrm{TiO}_{2}$ under visible irradiation ( $20 \mathrm{~W}$ lamp) after 60 minutes of reaction (with an energy consumption of $288 \mathrm{~kJ} / \mathrm{L}$ ). The high COD removals achieved is because the iron deposition on $\mathrm{TiO}_{2}$ surface improves the photocatalytic activity by suppressing the electron-hole recombination [36].
In our previous study [14], it was shown that the photodegradation of this commercial herbicide was enhanced by the use of ultrasound in the presence of $\mathrm{TiO}_{2}$ catalyst with COD removal of $84 \%$ at 150 minutes of UV light irradiation. The combination of these two processes (sonophotocatalysis) gave very high decomposition yields of the active compound (atrazine) reaching high degree of mineralization (97\%) [14]. Thus, a comparison of the results reported here with those obtained in our previous study using the sonophotocatalytic process, it is interesting to note that the employment of iron-doped $\mathrm{TiO}_{2}$ catalyst (under visible light) gives similar results at shorter time.

Figure 4(b) reports similar COD removal profiles under the UV lamp irradiation $(15 \mathrm{~W})$ with the achievement of higher COD removals in comparison with those reached under solar irradiation (with comparable energy consumption in both systems). From these results, it might be assumed that Fe-modification also improves inherent photocatalytic activity of the $\mathrm{TiO}_{2}$ powders to some extent because of an efficient charge separation of the UV light generated electron-hole pairs.

\section{Conclusions}

The gesaprim degradation rate depended on the iron content in the photo catalyst. The Fe-doped $\mathrm{TiO}_{2}(0.5 \%$ by weight of $\mathrm{TiO}_{2}$ ) showed higher TOC removal under visible light and was more active than the undoped $\mathrm{TiO}_{2}$ photo catalyst under the light irradiation sources tested. Over $90 \%$ of chemical oxygen demand abatement was achieved with both UV and visible light but less time was required to decrease the chemical oxygen demand content by using the catalyst doped with iron at $0.5 \%$ under visible light $(90 \%$ of TOC was removed after 200 min of photoreaction). It was observed that the degradation of gesaprim increased by increasing the iron content in the catalyst under visible light. This can be explained by the fact that the Fe(III) acted as scavenger of electrons photogenerated in $\mathrm{TiO}_{2}$ particles which let down holeelectron recombination.

This advanced oxidation process offers an environmental alternative for the treatment of water polluted with this commercial herbicide.

\section{Acknowledgements}

This work was financially supported by the Programa de Mejoramiento del Profesorado (PROMEP) of the Secretaría de Educación Pública (SEP). We thank CONACyT for the Grant given to N.A.Q and D.J.R.G. to support their postgraduate studies. 


\section{References}

[1] W. E. Pereira and C. E. Rostad, "Occurrence, Distributions, and Transport of Herbicides and Their Degradation Products in the Lower Mississippi river and Its Tributaryies," Environmental Science \& Technology, Vol. 24, 1990, pp. 1400-1406. doi:10.1021/es00079a015

[2] S. J. Kalkhoff, K. E. Lee, S. D. Porter, P. J. Terrio and E. M. Thurman, "Herbicides and Herbicide Degradation Products in Upper Midwest Agricultural Streams during August Base Flow Conditions," Journal of Environmental Quality, Vol. 32, No. 3, 2003, pp. 1025-1035.

doi:10.2134/jeq2003.1025

[3] C. A. Guzman-Perez, J. Soltan and J. Robertson, "Kinetics of Catalytic Ozonation of Atrazine in the Presence of Activated Carbon," Separation and Purification Technology, Vol. 79, No. 1, 2011, pp. 8-14. doi:10.1016/i.seppur.2011.02.035

[4] V.K. Gupta, B. Gupta, A. Rastogi, S. Agarwal, A. Nayak, "Pesticides Removal from Waste Water by Activated Carbon Prepared from Waste Rubber Tire," Water Research, Vol. 45, No. 13, 2011, pp. 4047-4055. doi:10.1016/j.watres.2011.05.016

[5] G.-C. Chen, X.-Q. Shen, Y.-Q. Zhou, X.-E. Shen, H.-L. Huang and S. U. Khan, "Adsorption Kinetics, Isotherms and Thermodynamics of Atrazine on Surface Oxidized Multiwalled Carbon Nanotubes," Journal of Hazardous Materials, Vol. 169, No. 1-3, 2009, pp. 912-918. doi:10.1016/j.jhazmat.2009.04.034

[6] T. S. Jamil, T. A. Gad-Allah, H. S. Ibrahim and T. S. Saleh, "Adsorption and Isothermal Models of Atrazine by Zeolite Prepared from Egyptian Kaolin," Solid State Sciences, Vol. 13, No. 1, 2011, pp. 198-203. doi:10.1016/j.solidstatesciences.2010.11.014

[7] I. K. Konstantinous, T. A. Albanis, D. E. Petrakis and P. J. Pomonis, "Removal of Herbicides from Aqueous Solutions by Adsorption on Al-Pillared Clays, Fe-Al Pillared Clays and Mesoporous Alumina Aluminum Phosphates," Water Research, Vol. 34, No. 12, 2000, pp. 3123-3136. doi:10.1016/S0043-1354(00)00071-3

[8] H. Chen, E. Bramanti, I. Longo, M. Onor and C. Ferrari, "Oxidative Decomposition of Atrazine in Water in the Presence of Hydrogen Peroxide Using an Innovative MiCrowave Photochemical Reactor," Journal of Hazardous Materials, Vol. 186, No. 2-3, 2011, pp. 1808-1815. doi:10.1016/j.jhazmat.2010.12.065

[9] K. V. Plakas and A. J. Karabelas, "Triazine Retention by Nanofiltration in the Presence of Organic Matter: The Role of Humic Substance Characteristics," Journal of Membrane Science, Vol. 336, No. 1-2, 2009, pp. 86-100. doi:10.1016/j.memsci.2009.03.020

[10] E. C. Wert, F. L. Rosario-Ortiz and S. A. Snyder, "Effect of Ozone Exposure on the Oxidation of Trace Organic Contaminants in Wastewater," Water Research, Vol. 43, No. 4, 2009, pp. 1005-1014. doi:10.1016/j.watres.2008.11.050

[11] S. Nélieu, L. Kerhoas and J. Einhorn, "Degradation of
Atrazine into Ammeline by Combined Ozone/Hydrogen Peroxide Treatment in Water," Environmental Science \& Technology, Vol. 34, No. 3, 2000. pp. 430-437. doi:10.1021/es980540k

[12] B. Balci, O. Nihal, C. Richard and A. O. Mehmet, "Degradation of Atrazine in Aqueous Medium by Electrocatalytically Generated Hydroxyl Radicals. A Kinetic and Mechanistic Study," Water Research, Vol. 43, No. 7, 2009. pp. 1924-1934. doi:10.1016/j.watres.2009.01.021

[13] D. Kassinos, N. Varnava, C. Michael and P. Piera, "Homogeneous Oxidation of Aqueous Solutions of Atrazine and Fenitrothion through Dark and Photo-Fenton Reactions," Chemosphere, Vol. 74, No. 6, 2009. pp. 866-872. doi:10.1016/j.chemosphere.2008.10.008

[14] C. Lizama-Bahena, S. Silva-Martínez, D. Morales-Guzman and M. R. Trejo-Hernández, "Sonophotocatalytic Degradation of Alazine and Gesaprim Commercial Herbicides in $\mathrm{TiO}_{2}$ Slurry," Chemosphere, Vol. 71, No. 5, 2008, pp. 982-989. doi:10.1016/j.chemosphere.2007.11.007

[15] L. Campanella and R. Vitaliano, "Atrazine Toxicity Reduction Following $\mathrm{H}_{2} \mathrm{O}_{2} / \mathrm{TiO}_{2}$-Photocatalyzed Reaction and Comparison with $\mathrm{H}_{2} \mathrm{O}_{2}$-Photolytic Reaction," Annali di Chimica, Vol. 97, No. 1-2, 2007, pp. 123-134. doi:10.1002/adic.200690081

[16] T. A. McMurray, P. S. M. Dunlop and J. A. Byrne, "The Photocatalytic Degradation of Atrazine on Nanoparticulate $\mathrm{TiO}_{2}$ Films," Journal of Photochemistry and Photobiology A: Chemistry, Vol. 182, No. 1, 2006, pp. 43-51. doi:10.1016/j.jphotochem.2006.01.010

[17] C. Lizama-Bahena and S. Silva-Martínez, "Photodegradation of Chlorbromuron, Atrazine, and Alachlor in Aqueous Systems under Solar Irradiation," International Journal of Photoenergy, Vol. 81808, 2006, pp. 1-6.

[18] I. Texier, J. Ouazzani, J. Delaire and C. Giannotti, "Study of the Mechanisms of the Photodegradation of Atrazine in the Presence of Two Photocatalysts: $\mathrm{TiO}_{2}$ and $\mathrm{Na}_{4} \mathrm{~W}_{10} \mathrm{O}_{32}$," Tetrahedron, Vol. 55, No. 11, 1999, pp. 3401-3412. doi:10.1016/S0040-4020(98)01150-8

[19] Y. Zhang, Y. Li and X. Zheng, "Removal of Atrazine by Nanoscale Zero Valent Iron Supported on Organobentonite," Science of the Total Environment, Vol. 409, No. 3, 2011, pp. 625-630. doi:10.1016/j.scitotenv.2010.10.015

[20] K. Hustert, P. N. Moza and B. Pouyet, "Photocatalytic Degradation of S-Triazines Herbicides," Toxicological \& Environmental Chemistry, Vol. 51, No. 52, 1993, pp. 96-101.

[21] S. M. Arnold, W. J. Hickey and R. F. Harris, "Degradation of Atrazine by Fenton's Reagent: Condition, Optimization and Product Quantification," Environmental Science \& Technology, Vol. 29, No. 8, 1995, pp. 20832089. doi:10.1021/es00008a030

[22] E. Pelizzeti, V. Maurino, C. Minero, V. Carlin, E. Pramauro, O. Zerbinati and M. L. Tosato, "Photocatalytic Degradation of Atrazine and Other S-Triazine Herbicides," Environmental Science \& Technology, Vol. 24 No. 10, 1990, pp. 1559-1565. doi:10.1021/es00080a016 
[23] I. K. Konstantinou and T. A. Albanis, "Photocatalytic Transformation of Pesticides in Aqueous Titanium Dioxide Suspensions Using Artificial and Solar Light: Intermediates and Degradation Pathways," Applied Catalysis B: Environmental, Vol. 42, No. 4, 2003, pp. 319-335. doi:10.1016/S0926-3373(02)00266-7

[24] V. Hequet, C. Gonzalez and P. Le-Cloirec, "PhotoChemical Processes for Atrazine Degradation: Methodological Approach," Water Research, Vol. 35, No. 18, 2001, pp. 4253-4260. doi:10.1016/S0043-1354(01)00166-X

[25] G. A. Peñuela and D. Barceló, "Comparative Photodegradation Study of Atrazine and Desethylatrazine in Water Samples Containing Titanium," Journal of AOAC International, Vol. 83, No. 1, 2000, pp. 53-60.

[26] H. Měšt'ánková, J. Krýsa, J. Jirkovský, G. Mailhot and M. Bolte, "The influence of Fe(III) Speciation on Supported $\mathrm{TiO}_{2}$ Efficiency: Example of Monuron Photocatalytic Degradation," Applied Catalysis B: Environmental, Vol. 58, No. 3-4, 2005, pp. 185-191. doi:10.1016/j.apcatb.2003.09.017

[27] K. Horst, G. Burgeth and W. Macyk, "Visible Light Photocatalysis by a Titania Transition Metal Complex," Advances in Inorganic Chemistry, Vol. 56, 2004, pp. 241259. doi:10.1016/S0898-8838(04)56008-7

[28] M. Anpo, "Preparation, Characterization, and Reactivities of Highly Functional Titanium Oxide-Based Photocatalysts Able to Operate under UV-Visible Light Irradiation: Approaches in Realizing High Efficiency in the Use of Visible Light," Bulletin of the Chemical Society of Japan, Vol. 77, No. 8, 2004, pp. 1427-1442. doi:10.1246/bcsj.77.1427

[29] Y. Aita, M. Komatsu, S. Yin and T. Sato, "Phase-Compositional Control and Visible Light Photocatalytic Activity of Nitrogen-Doped Titania via Solvothermal Process," Journal of Solid State Chemistry, Vol. 177, No. 9, 2004, pp. 3235-3238. doi:10.1016/j.jssc.2004.04.048
[30] M. S. Diallo and S. Nora, "Nanoparticles and water quality," Journal of Nanoparticle Research, Vol. 7, No. 4-5, 2005, pp. 325-330. doi:10.1007/s11051-005-8543-x

[31] N. Wetchakun, P. Pirakitikulr, K. Chiang and S. Phanichphant, "Visible Light-Active Nano-Sized Fe-Doped $\mathrm{TiO}_{2}$ Photocatalysts and Their Characterization," 2nd IEEE International Nanoelectronics Conference, Shanghai, 2008, pp. 836-841.

[32] Z. Ambrus, N. Balázs, T. Alapi, G. Wittmann, P. Sipos, A. Dombi and K. Mogyorósi, "Synthesis, Structure and Photocatalytic Properties of $\mathrm{Fe}(\mathrm{III})$-Doped $\mathrm{TiO}_{2}$ Prepared from $\mathrm{TiCl}_{3}$," Applied Catalysis B: Environmental, Vol. 81, No. 1-2, 2008, pp. 27-37. doi:10.1016/j.apcatb.2007.11.041

[33] M. K. Seery, G. Reenamole, P. Floris and S. Pillai, "Silver Doped Titanium Dioxide Nanomaterials for Enhanced Visible Light Photocatalysis," Journal of Photochemistry and Photobiology A: Chemistry, Vol. 189, No. 2-3, 2007, pp. 259-263. doi:10.1016/j.jphotochem.2007.02.010

[34] B. Tryba, "Increase of the Photocatalytic Activity of $\mathrm{TiO}_{2}$ by Carbon and Iron Modifications," International Journal of Photoenergy, Vol. 2008, 2008, pp. 1-15. doi: $10.1155 / 2008 / 721824$

[35] A. Katsambas, C. A. Varotsos, G. Veziryianni and C. Antoniou, "Surface Solar Ultraviolet Radiation: A Theoretical Approach of the SUVR Reaching the Ground in Athens, Greece," Environmental Science and Pollution Research, Vol. 4, No. 2, 1997, pp. 69-73. doi:10.1007/BF02986280

[36] U. I. Gaya and H. A. Abdul, "Heterogeneous Photocatalytic Degradation of Organic Contaminants over Titanium Dioxide: A Review of Fundamentals, Progress and Problems," Journal of Photochemistry and Photobiology C: Photochemistry Reviews, Vol. 9, No. 1, 2008, pp. 1-12. doi:10.1016/j.jphotochemrev.2007.12.003 